\title{
Spontaneous pneumothorax complicating lung emphysema. So, what's the catch?
}

\author{
Stylianos Mavridis, Hans-Georg Gnauk, Martina Schumacher, Roland H. Wagner
}

Vascular and Thoracic Surgery Department, Ernst von Bergmann Clinic, Potsdam, Germany

\begin{abstract}
Abstrak
Pneumotoraks spontan sekunder dari karsinoma paru terjadi sangat jarang (0,05\% dari seluruh pneumotoraks). Kami melaporkan sebuah kasus dari pria berusia 66 tahun dengan pneumotoraks spontan persisten sebelah kanan, yang pada mulanya dicurigai sekunder dari emfisema bulosa. Penemuan intraoperasi berupa bula di bagian apeks dengan karnifikasi non-spesifik pada bagian dasar dan sebuah bula pada lobus inferior. Secara mengejutkan, pemeriksaan histologi menampakkan karsinoma bukan sel kecil yang tidak terdefinisi. Meskipun pneumotoraks spontan yang berhubungan dengan karsinoma paru jarang terjadi, kecurigaan keganasan perlu ditingkatkan pada pasien di atas 40 tahun dengan pneumotoraks spontan, khususnya pasien risiko tinggi seperti perokok atau pasien dengan bronkitis kronik atau emfisema. (Med J Indones. 2013;22:54-6)
\end{abstract}

\begin{abstract}
Spontaneous pneumothorax secondary to lung carcinoma is very rare $(0.05 \%$ of all pneumothoraces). We report a case of a 66-year-old male with persistent right-sided spontaneous pneumothorax, initially suspected as secondary to bullous emphysema. Intraoperative findings consisted of an apical bulla with a nonspecific carnification at its base and a bulla at the lower lobe. Surprisingly, histological examination revealed an undefined non-small cell carcinoma. Although spontaneous pneumothorax associated with lung carcinoma is rare, suspicion for malignancy should be raised in patients over 40 presenting with spontaneous pneumothorax, especially in high risk patients such as smokers or patients with chronic bronchitis or emphysema. (Med J Indones. 2013;22:54-6)
\end{abstract}

Keywords: Emphysema, lung cancer, pneumothorax

The presence of air in the pleural cavity defines the pneumothorax, which can be spontaneous, traumatic or iatrogenic. Spontaneous pneumothorax (SP) can be classified as primary or secondary. The primary spontaneous pneumothorax (PSP) is common among young population especially thin, tall males without previous lung disease, whereas the secondary spontaneous pneumothorax (SSP) is often in the elderly with underlying parenchymal lung disease such as COPD, bullous emphysema, pulmonary tuberculosis and other pulmonary infections, cystic fibrosis, idiopathic pulmonary fibrosis, lymphangioleiomyomatosis etc. ${ }^{1,2}$ Primary bronchogenic carcinoma or lung metastases have been sporadically described as a potential cause of SP, with an estimated rate of joint occurrence between 0.03 and $0.05 \%$ for primary bronchogenic carcinoma. ${ }^{3,4,5}$ Treatment of SP ranges from simple observation, needle aspiration, tube thoracostomy or chemical pleurodesis to video-assisted thoracoscopy or thoracotomy.

We report the case of a patient treated with thoracotomy for persistent SSP where unexpectedly a non-small cell lung carcinoma of undefined histology was detected.

\section{CASE ILLUSTRATION}

A 66-year old male, heavy smoker with a previous medical history of chronic obstructive pulmonary disease with chronic bronchitis and pulmonary emphysema was referred to our institution in February 2011 due to progressive dyspnea worsening the last two days. Chest pains or fever were denied. At the time of admission showed mild hypertension $(150 / 80 \mathrm{mmHg})$, rhythmic heart beat of $110 / \mathrm{min}$, normal breathing rate $(24 / \mathrm{min})$, oxygen saturation of $87 \%$ and normal body temperature $\left(36.5^{\circ} \mathrm{C}\right)$. White blood cell count and C-reactive protein concentration were elevated to $15.5 \mathrm{Gpt} / \mathrm{L}$ and $228.80 \mathrm{mg} / \mathrm{L}$, respectively. Chest radiograph revealed a right-sided large pneumothorax without mediastinal shift (Figure 1A). Rupture of an emphysematous bulla causing pneumothorax was suspected and a 24 Charrière chest tube was inserted after local anesthetic injection in the $4^{\text {th }}$ intercostal space at anterior axillary line and attached to underwater seal. The chest X-Ray taken afterwards demonstrated the incomplete expansion of the lung so consequently the drain was placed on suction (Figure 1B). CT scan on the fourth day exhibited the bullous emphysema, moderate subcutaneous emphysema, a $7 \mathrm{~cm}$ apical bulla on the right side with an irregular fibrotic infiltration of segment 1 of the right lung. On the left side, a $3.8 \mathrm{~cm}$ apical bulla was noticed (Figure 2).

Because of the persistent pneumothorax with air leak, the patient was scheduled for the OR. Until now, no suspicion of a malignant disease was raised. Antero-lateral thoracotomy was performed on the sixth post-tubing day. At surgery the apical bulla was detected on segment 1, demonstrating a nonspecific carnification of its base. 


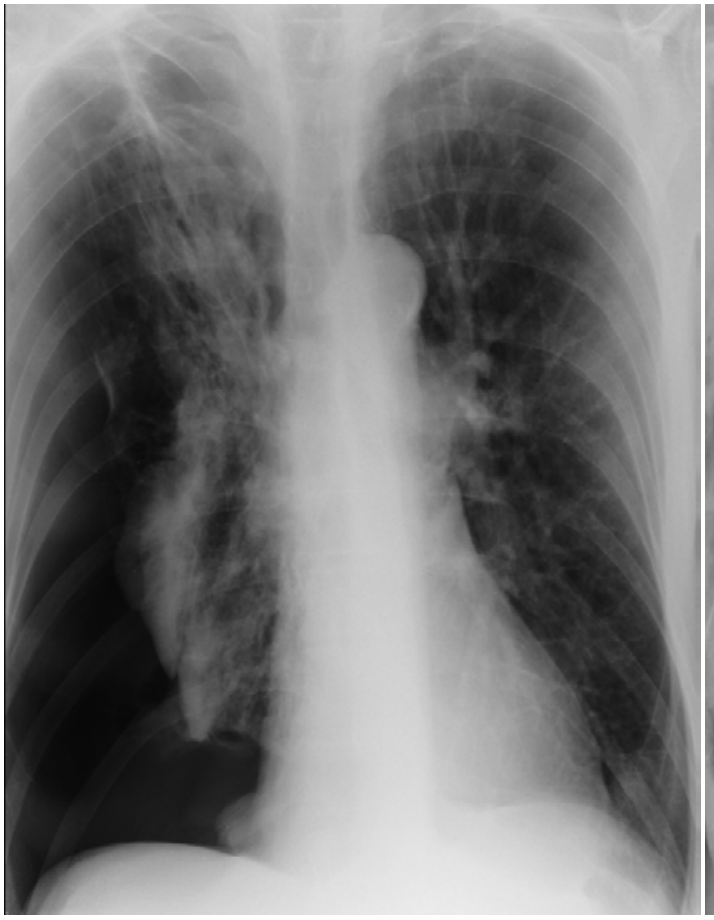

A

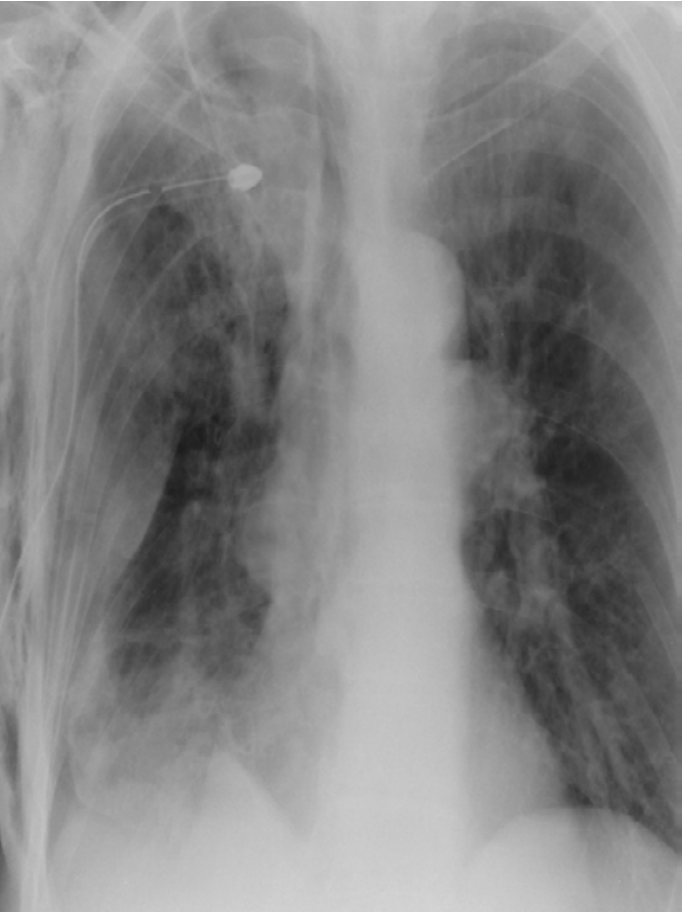

$\mathrm{B}$

Figure 1. A) Right sided pneumothorax with a slight mediastinal shift, B) post-tubing state

Therefore segmentectomy was performed. Furthermore another smaller bulla was observed on the right lower lobe, so wedge resection was carried out. Following this, partial pleurectomy completed the surgical procedure.

Chest drain was removed on the sixth postoperative day with patient's course being uneventful. Hospital discharge was scheduled on the tenth day.

Surprisingly, histological examination revealed a low grade polymorphous and partially clear cell trabecular carcinoma (non-small cell cancer type) at the base of the bulla, with a maximal diameter of $11 \mathrm{~mm}$, resected in R0. A further histological differentiation was not possible. No other metastases were detected and due to patient's impaired lungfunction and reduced clinical state no further treatment was performed.

\section{DISCUSSION}

Spontaneous pneumothorax remains a common pathology with an incidence between 18-28/100000 p.a. in males and $1.2-6 / 100000$ p.a. in females. ${ }^{6} \mathrm{SSP}$ is often from the end of the fourth decade due to progressive intrathoracic pathology in high risk population such tobacco smokers or COPD patients, resulting from a ruptured bleb or bulla into the visceral pleura. ${ }^{4}$ Lung cancer can also occur in the same high risk group.
SP as the first manifestation of bronchogenic carcinoma is extremely rare, and only $2 \%$ of all SP coincides with a malignant lung pathology, primary or secondary. ${ }^{3}$ Four possible mechanisms responsible for SP in lung carcinoma have been theorized. (1) The genesis of a bronchopleural communication secondary to tumor necrosis (e.g. after chemotherapy) and rupture into a bronchus or pleural cavity. (2) The spontaneous rupture of dilated alveoli or subpleural blebs distal to bronchial obstruction due to lung carcinoma. (3) The direct local pleural infiltration by the neoplasm. (4) Coincidental rupture of bullous emphysema either spontaneous or due to disturbance of the lung architecture caused by the neoplasm..$^{3,4,5}$ Moreover, SP is also been described in metastatic lung disease, mostly in affiliation with metastatic sarcomas, germ cell tumors or lymphomas with lung infiltration. ${ }^{5}$

In our patient, preoperative thorax CT scan didn't raise any suspicion for an underlying malignant disease. In many cases of SSP secondary to lung carcinoma, diagnosis is late, delaying the proper and prompt treatment.

In the international bibliography, primary squamous cell carcinoma of the lung has the predominance among carcinomas responsible for SSP $(50 \%$ as demonstated in Steinhäuslin and Cuttat $)^{4}$ followed by the adenocarcinoma (18.2\%) and the giant cell carcinoma 


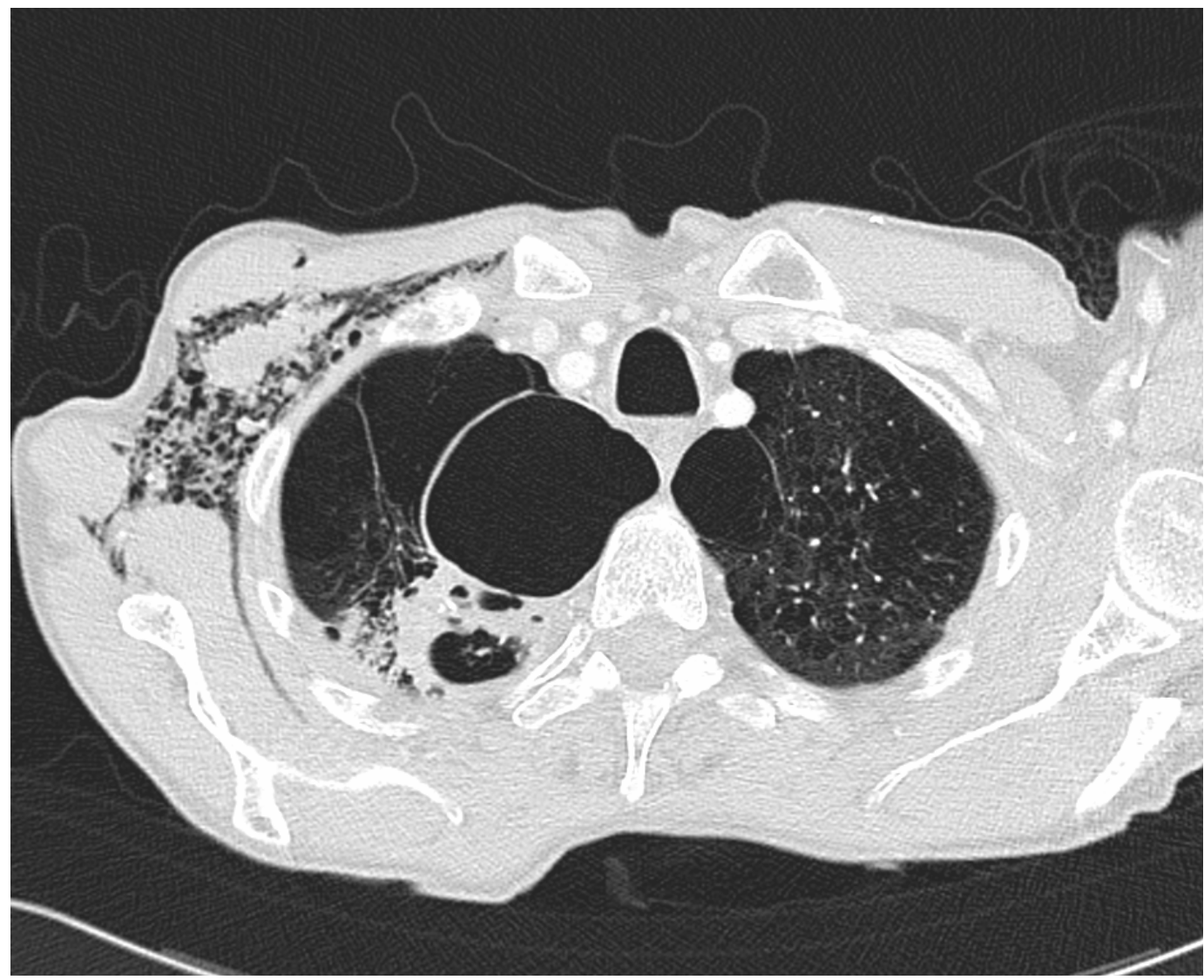

Figure 2. Bilateral apical bullae with an irregular fibrotic infiltration of segment 1 of the right lung

(11.4\%). The same authors found in $6.8 \%$, of the 46 reviewed cases, carcinomas of undefined histology. In our case, our Pathology Division was unable to define the exact histology of the neoplasm at the ground of the resected bulla. Due to patients impaired status no other therapy was conducted.

To summarize, although SSP associated with lung carcinoma is a rare entity, we think that suspicion for malignancy should be raised in patients over 40 presenting with SP, especially in high risk patients such as smokers or patients with chronic bronchitis or emphysema.

\section{Acknowledgments}

Written informed consent was obtained from the patient for publication of this case report and any accompanying images. A copy of the written consent is available for review from the editorial office of Medical Journal of Indonesia.

\section{REFERENCES}

1. Weissberg D, Rafaely Y. Pneumothorax. Chest. 2000;117:1279-89.

2. Kim SJ, Lee HS, Kim HS, et al. Outcome of videoassisted thoracoscopic surgery for spontaneous secondary pneumothorax. Koren J Thorac Cardiovasc Surg. 2011;44:225-8.

3. Vencevičius V, Cicènas S. Spontaneous pneumothorax as a first sign of pulmonary carcinoma. World Journal of Surgical Oncology. 2009;7:57.

4. Steinhäuslin CA, Cuttat JF. Spontaneous pneumothorax. A complication of lung cancer? Chest. 1985,88:709-13.

5. O'Connor BM, Ziegler P, Spaulding MB. Spontaneous pneumothorax in small cell lung cancer. Chest. 1992;102:628-9.

6. Sousa C, Neves J, Sa N, et al. Spontaneous pneumothorax: a 5-year experience. J Clin Med Res. 2011;3:111-7. 